\title{
MENCIPTAKAN HIGH LEVEL OF PLAY DALAM RENCANA PEMBELAJARAN ANAK USIA DINI
}

\author{
Maria Melita Rahardjo \\ FKIP PG-PAUD Universitas Kristen Satya Wacana \\ maria.melita@staff.uksw.edu
}

\begin{abstract}
ABSTRAK
Bermain adalah filosofi dasar pembelajaran anak usia dini di Indonesia. Oleh karenanya, penelitian ini bertujuan untuk mememeriksa dan menganalisa secara teoritis rancangan pembelajaran yang dapat mendukung implementasi prinsip bermain level tinggi atau high level of play dalam kurikulum Pendidikan Anak Usia Dini (PAUD) tersebut. Setiap pembelajaran AUD hendaknya dapat mengintegrasikan high level of play ke dalamnya karena studi dan penelitian yang ada menyatakan bahwa hal tersebut dapat mengembangkan semua aspek perkembangan anak secara optimal. Penelitian ini melibatkan sepuluh kelompok partisipan dan masing-masing kelompok merancang sebuah rencana pelaksanaan pembelajaran harian (RPPH). Dokumen RPPH disusun mengacu pada kurikulum 2013 PAUD dan kesepuluh kelompok mengembangkan sistem pembelajaran berbasis sentra. Dokumen RPPH yang mereka rancang kemudian mereka presentasikan dalam bentuk simulasi penataan lingkungan belajar. Dokumen RPPH, diskusi dan wawancara partisipan, serta observasi hasil penataan lingkungan belajar menjadi sumber data utama penelitian deskriptif kualitatif ini. Hasil penelitian menemukan bahwa setidaknya ada tiga faktor penting yang berperan dalam perencanaan pembelajaran yang dapat menginisiasi high level of play. Ketiga faktor tersebut adalah material, penataan material, dan guru. Selanjutnya, salah satu keterbatasan penelitian ini adalah bahwa rancangan RPPH yang disusun tidak dilanjutkan hingga tahap implementasi di kelas AUD. Penelian selanjutnya disarankan untuk melihat analisa teoritis hasil wawancara dan diskusi apakah benar perencanaan pembelajaran yang dihasilkan mampu menginisiasi high level of play pada pembelajaran anak usia dini.
\end{abstract}

Kata kunci: bermain, lingkungan belajar, kurikulum PAUD, high level of play

\section{PENDAHULUAN}

Kurikulum 2013 PAUD menganut filosofi pembelajaran yang berpusat pada anak. Filosofi yang mendasari pengembangan kurikulum PAUD tersebut berusaha dicapai dengan pembelajaran melalui pendekatan bermain. Hal tersebut ditekankan di dalam dokumen kerangka dasar dan struktur kurikulum, dokumen pedoman pengembangan Kurikulum Tingkat Satuan Pendidikan (KTSP), dan dokumen pedoman pembelajaran. Meskipun demikian, pembelajaran melalui pendekatan bermain mengalami beberapa tantangan pada praktik implementasinya. Salah satu hal yang diduga menjadi faktor penghambatnya adalah tradisi panjang pembelajaran AUD di Indonesia yang menekankan pada instruksi guru (teacher-directed approach).

Studi pendahuluan yang dilakukan peneliti dengan mengamati dan mewawancarai beberapa guru senior mendapat hasil bahwa mereka terbiasa melakukan pembelajaran di kelas dengan mengajar di depan kelas, di hadapan murid-murid AUD yang duduk dan mendengarkan mereka. Selain itu, ciri khas pembelajaran teacher-directed lainnya adalah dengan menginstruksikan anak untuk melakukan kegiatan pembelajaran yang sama dalam waktu bersamaan. Sebagai contoh, setelah mendengarkan sebuah cerita tentang ulat yang memakan buah, guru kemudian menyediakan kertas gambar dan crayon dan meminta semua anak di kelas untuk menggambar buah yang mereka suka. Dalam kasus ini, semua anak memulai dan mengakhiri kegiatan dalam waktu sama, mendapat bahan dan material 
yang sama, dan melakukan kegiatan yang sama. Dalam skema pembelajaran tersebut, guru seakanakan mengabaikan minat siswa untuk belajar tentang buah melalui media lain (clay, dummy buah, buku bergambar, dan sebagainya) dan membatasi hanya pada media kertas dan crayon.

Salah satu faktor utama agar pembelajaran melalui pendekatan bermain dapat berhasil diimplementasikan dalam pendidikan AUD adalah guru kelas. Pertama, guru kelas merupakan penanggung jawab utama yang merencanakan rencana pembelajaran. Kedua, guru kelas jugalah yang akan mengelola kelas untuk menunjang keberhasilan implementasi rencana pembelajaran tersebut. Oleh karena itu, calon pendidik (guru) AUD yang masih menempuh pendidikan guru - pendidikan anak usia dini dibekali dengan mata kuliah pengembangan kurikulum PAUD. Para calon guru ini nantinya diharapkan untuk mampu merencanakan pembelajaran yang sesuai dengan filosofi dasar pengembangan kurikulum PAUD yaitu pembelajaran melalui pendekatan bermain.

Satu hal yang perlu menjadi perhatian adalah bahwa konsep bermain sambil belajar merupakan hal yang selalu didengungkan bagi pendidikan anak usia dini. Namun Rahardjo (2016) merasa bahwa pemahaman konsep bermain yang dangkal akan menghambat integrasi pendekatan bermain pada proses pembelajaran anak usia dini. Kekurang pahaman guru akan konsep bermain disinyalir dapat menghambat perencanaan pembelajaran yang mengintegrasikan high level of play ke dalamnya. Hal ini akan merugikan anak didik karena studi dan penelitian menyatakan bahwa high level of play dapat mengoptimalkan perkembangan fisik-motorik, kognitif-bahasa, dan sosioemosional anak.

Mengingat bahwa bermain merupakan landasan filosofi pembelajaran anak usia dini, maka seluruh aspek pengembangan kurikulum AUD pun haruslah merefleksikan landasan tersebut dalam prakteknya. Bertolak dari hal tersebut, salah satu luaran dari calon guru PAUD yang mengambil mata kuliah pengembangan kurikulum PAUD adalah mampu merencanakan pembelajaran yang mengintegrasikan prinsip bermain di dalamnya.

Berdasar paparan di atas, maka penelitian ini bertujuan untuk menganalisa secara teoritis apakah model pembelajaran yang dikembangkan oleh calon guru PAUD yang mengambil mata kuliah 'Pengembangan Kurikulum PAUD' sudah berpotensi untuk mengembangkan pembelajaran yang mengintegrasikan high level of play di dalamnya.

\section{KAJIAN PUSTAKA}

\section{Kurikulum Pendidikan Anak Usia Dini di Indonesia}

Pendidikan anak usia dini di Indonesia memasuki babak baru dengan diterbitkannya Standar Nasional Pendidikan Anak Usia Dini (SN PAUD) untuk pertama kalinya di tahun 2009 yang diatur dalam Peraturan Menteri Pendidikan nomor 58 tahun 2009. Standar nasional pertama tersebut mengatur empat kelompok standar, antara lain: (1) Standar tingkat pencapaian perkembangan; (2) Standar pendidik dan tenaga kependidikan; (3) Standar isi, proses, dan penilaian; dan (4) Srandar sarana dan prasarana, pengelolaan, dan pembiayaan (Kementrian Pendidikan dan Kebudayaan, 2009). Standar nasional PAUD tersebut kemudian diperbaharui dengan Peraturan Menteri nomor 137 tahun 2014.

Salah satu perubahan yang signifikan dari peraturan menteri nomor 58 tahun 2009 ke nomor 137 tahun 2014 adalah terbitnya kurikulum PAUD (Kementrian Pendidikan dan Kebudayaan, 2014b). Peraturan menteri nomor 58 tahun 2009 memang telah mengatur tentang program pengembangan pembelajaran untuk anak usia dini, tetapi istilah "kurikulum" belumlah resmi dipakai. Baru pada tahun 2014, dokumen kurikulum PAUD yang dikenal dengan nama "Kurikulum 2013 Pendidikan Anak Usia Dini” diterbitkan sebagai pelengkap Standar Nasional PAUD (Kementrian Pendidikan dan 
Kebudayaan, 2014c).

Salah satu hal yang menjadi kekhasan kurikulum PAUD adalah "pembelajaran berdasar prinsip bermain". Ciri tersebut menjadi pembeda dengan kurikulum PAUD dengan kurikulum jenjang pendidikan lain. Jika dicermati, kekhasan tersebut berkali-kali muncul di sepanjang dokumen kurikulum.

Pertama, dalam landasan filosofis pengembangan kurikulum PAUD dikatakan bahwa pembelajaran dan kegiatan yang dikembangkan harus didasarkan pada prinsip bermain. Hal ini berbeda dengan landasan filosofis kurikulum 2013 jenjang pendidikan SD/ MI misalnya, yang menekankan pada pembelajaran untuk pengembangan kecerdasan intelektual, kecemerlangan akademik, dan kemampuan berpikir reflektif (Kementrian Pendidikan dan Kebudayaan, 2014a). Landasan filosofis ini penting untuk dicermati karena landasan inilah yang memberi arah tujuan pendidikan anak usia dini, menunjukkan nilai dasar yang dianut, dan memberi pedoman strategi pencapaian tujuan (Sanjaya, 2008).

Prinsip bermain juga kembali muncul dalam struktur muatan kurikulum. Disebutkan bahwa enam aspek program pengembangan muatan kurikulum PAUD (nilai agama dan moral - fisik/motorik - kognitif - bahasa - sosio/emosional - dan seni) diimplementasikan dalam konteks bermain. Selanjutnya, prinsip bermain kembali ditegaskan dalam pedoman pengembangan KTSP PAUD. Pendekatan belajar melalui bermain menjadi salah satu prinsip yang perlu diperhatikan dalam penyusunan kurikulum PAUD. Terakhir, prinsip bermain juga muncul di pedoman pembelajaran. Pedoman pembelajaran adalah dokumen kurikulum yang memuat strategi pembelajaran, strategi pengelolaan kelas, dan metode pembelajaran.

Kesimpulannya, pengembangan kurikulum PAUD kental dengan nuansa bermain. Pembelajaran melalui pendekatan bermain menjadi ciri khas pembelajaran pada anak usia dini. Karenanya, tenaga pendidik dan kependidikan, khususnya guru kelas pengembang kurikulum PAUD perlu memahami prinsip bermain supaya dapat mengembangkan kurikulum yang sesuai dengan pedoman yang telah ditetapkan.

\section{Bermain pada Anak Usia Dini}

Prinsip bermain yang diadopsi ke dalam kurikulum PAUD menjadi sebuah tantangan baru bagi para pendidik AUD di Indonesia. Salah satu alasannya adalah karena praktik pendidikan AUD di Indonesia telah lama menggunakan pendekatan behaviorist (Rahardjo, 2016). Pendekatan tersebut kental dengan model-model pembelajaran yang berciri teacher-directed (Wolfgang and Wolfgang, 1992). Sebaliknya, pendekatan bermain adalah pendekatan yang senada dengan pendekatan studentcentered yang letaknya dalam garis kontinuum adalah saling berseberangan dengan pendekatan teacher-directed (Rahardjo, 2016).

Perubahan pendekatan pembelajaran pada anak usia dini yang kini mulai diadopsi di Indonesia adalah hasil dari berbagai studi dan penelitian yang telah dilakukan oleh para ahli yang menekuni bidang pendidikan anak usia dini. Berbagai studi dan penelitian menghasilkan suatu simpulan yaitu pembelajaran dengan pendekatan bermain dirasa paling sesuai dan paling menguntungkan untuk mengoptimalkan perkembangan anak usia dini secara holistik. Rahardjo (2016) menyebutkan bahwa pendekatan bermain memang pendekatan yang dirasa paling sesuai bagi pembelajaran anak usia dini karena dapat mengoptimalkan semua aspek perkembangan anak, mengkoneksikan semua koneksi di otak, dan menjadikan anak sebagai pembelajar yang kompeten. Hal senada juga diungkapkan oleh Bodrova and Leong (2003) bahwa kualitas pengalaman bermain yang didapat oleh anak akan menentukan kesuksesan anak di jenjang pendidikan selanjutnya.

Dalam rangka menciptakan sebuah pembelajaran yang mengintegrasikan kualitas bermain yang baik (high level of play) seperti yang diungkapkan oleh Bodrova dan Leong, diperlukan sebuah 
pemahaman konsep tentang bermain. Pemahaman konsep dapat dicapai melalui pemahaman definisi bermain. Kenyataannya, banyak sekali definisi bermain yang dikemukakan para ahli. Oleh karena itu Rahardjo (2016) berusaha menjabarkan definisi tersebut dalam enam karakteristik bermain sebagai berikut:

1. Motivasi intrinsik: kegiatan bermain datang dari keinginan anak. Bermain merupakan pilihan bebas dan sukarela anak.

2. Partisipasi aktif: anak dengan sadar melibatkan dirinya (fisik dan mental) ke dalam kegiatan tersebut.

3. Menyenangkan

4. Kontrol/ peraturan intrinsik: pembuat aturan utama adalah si anak. Anak yang menentukan bagaimana jalannya bermain dan bagaimana sebuah material digunakan.

5. Orientasi pada proses - bukan hasil.

6. Nonliteral: bermain melibatkan imajinasi pada porsi tertentu. Terjadi sebuah distorsi realita dalam rangka mengakomodasi kepentingan pemain.

Keenam karakteristik tersebut dapat membantu pendidik anak usia dini untuk memaknai sebuah aktivitas/ kegiatan anak, apakah kegiatan tersebut termasuk bermain atau bukan. Untuk disebut bermain, sebuah kegiatan hendaknya menggambarkan hampir semua karakteristik tersebut secara bersamaan, walaupun dalam derajat yang berbeda untuk tiap-tiap poin.

\section{METODE}

Penelitian ini menggunakan pendekatan kualitatif deskriptif (Nazir, 2005). Selanjutnya, Nazir (2005) menjelaskan bahwa metode deskriptif kualitatif adalah sebuah metode yang digunakan untuk meneliti sebuah objek, kondisi, atau suatu peristiwa pada masa sekarang. Tujuan dari metode ini adalah memberi gambaran atau deskripsi secara sistematis, akurat, dan faktual atas fenomena atau suatu keadaan yang sedang diteliti.

Metode pengambilan data pada penelitian ini adalah dengan melalui observasi langsung, dokumentasi, dan wawancara. Ketiga teknik pengumpulan data tersebut sekaligus digunakan sebagai metode triangulasi data untuk mendukung validasi hasil pengumpulan data (Sanjaya, 2013).

Penelitian ini melibatkan 10 kelompok partisipan dan masing-masing kelompok terdiri dari tiga sampai empat orang. Pada minggu pertama, masing-masing kelompok berdiskusi dan membuat dokumen Rencana Pelaksanaan Pembelajaran Harian (RPPH). RPPH yang dirancang oleh setiap kelompok mengacu pada dokumen kurikulum 2013. Setiap kelompok menentukan jenis layanan PAUD yang (KB/ TK), kelompok usia anak yang dilayani, dan waktu pembelajaran yang dialokasikan dalam satu hari. Kelompok usia anak dan alokasi waktu pembelajaran menjadi dasar untuk mengembangkan kegiatan pembuka, kegiatan inti, dan kegiatan penutup dalam RPPH mereka. Sistem pengelolaan kelas yang digunakan oleh kesepuluh kelompok partisipan adalah "sistem sentra". Masing-masing kelompok kemudian memilih lima jenis sentra untuk dikembangkan dalam rencana pembelajaran mereka.

Setelah merancang RPPH, masing-masing kelompok mempresentasikan rencana pembelajaran mereka di laboratorium PG-PAUD UKSW. Dalam presentasi tersebut, mereka menata lingkungan belajar sesuai dengan rencana pembelajaran yang mereka lakukan. Presentasi oleh kesepuluh kelompok partisipan dilakukan dalam waktu dua minggu secara bergiliran. Setiap harinya ada satu hingga dua kelompok yang melakukan presentasi. Dalam presentasi, setiap kelompok menata kelima sentra seperti yang telah mereka rencanakan di RPPH mereka. Ruang laboratorium PG PAUD UKSW mereka simulasikan menjadi lima sentra. 
Selanjutnya, setiap kali masing-masing kelompok melakukan praktik presentasi, peneliti menanyakan pertanyaan terbuka kepada semua anggota tim selepas mereka menjelaskan rencana pembelajaran dan penataan lingkungan belajar yang mereka lakukan. Jawaban pertanyaan dan hasil diskusi dengan seluruh kelompok partisipan menjadi data pelengkap observasi dan dokumentasi yang ada.

Sepuluh kelompok data yang didapat kemudian dianalisa dengan mengkodekan dan mengelompokkan jawaban hasil diskusi, observasi, dan dokumen ke dalam tiga tema besar: rencana pembelajaran yang disinyalir dapat mendukung proses belajar melalui pendekatan bermain level tinggi, level menengah, dan level rendah. Pengkodean dan pengelompokkan dilakukan dengan menggunakan indikator deskriptif yang dikembangkan dari enam karakteristik konsep bermain. Berikut ini adalah indikator deskrptif yang dikembangkan oleh peneliti:

Tabel 1. Indikator pengukuran level bermain

\begin{tabular}{|c|c|}
\hline $\begin{array}{l}\text { Karakteristik Bermain } \\
\text { (Rahardjo, 2016) }\end{array}$ & Contoh indikator deskriptif \\
\hline 1. Motivasi intrinsik & $\begin{array}{l}\text { - Apakah material yang dipilih dapat menimbulkan } \\
\text { ketertarikan anak untuk berinteraksi? } \\
\text { - } \text { Apakah ada kebebasan untuk mengeksplorasi material } \\
\text { yang telah disiapkan? } \\
\text { - Apakah material dan lingkungan belajar fisik ditata } \\
\text { dengan indah? }\end{array}$ \\
\hline 2. Partisipasi aktif & $\begin{array}{l}\text { - Apakah guru menggunakan media nyata selain kertas? } \\
\text { - Apakah ada objek/ benda nyata yang menarik bagi } \\
\text { anak? } \\
\text { - } \quad \text { Apakah material dekat dengan keseharian anak }\end{array}$ \\
\hline 3. Menyenangkan & $\begin{array}{l}\text { - Apakah ada paksaan untuk anak mengikuti kegiatan } \\
\text { pembelajaran yang disiapkan? } \\
\text { - Apakah ada paksaan anak untuk berinteraksi dengan } \\
\text { material yang disiapkan? } \\
\text { - Apakah material dan lingkungan belajar fisik ditata } \\
\text { dengan indah? }\end{array}$ \\
\hline $\begin{array}{l}\text { 4. } \begin{array}{l}\text { Kontrol/ } \\
\text { intrinsik }\end{array}\end{array}$ & $\begin{array}{l}\text { - Apakah ada produk akhir yang diharapkan untuk } \\
\text { dihasilkan oleh anak-anak } \\
\text { - Apakah anak harus mengikuti prosedur tertentu dalam } \\
\text { sebuah kegiatan pembelajaran }\end{array}$ \\
\hline $\begin{array}{l}\text { 5. Orientasi pada proses - } \\
\text { bukan hasil }\end{array}$ & $\begin{array}{l}\text { - Apakah material/ bahan yang disiapkan dapat } \\
\text { digunakan anak untuk tujuan lain selain tujuan yang } \\
\text { sudah dirumuskan oleh guru dalam RPPH } \\
\text { - Apakah guru akan menoleransi penggunaan material/ } \\
\text { bahan yang tidak sesuai dengan yang direncanakan } \\
\text { guru }\end{array}$ \\
\hline 6. Nonliteral & $\begin{array}{l}\text { - Apakah material yang disiapkan dapat digunakan } \\
\text { untuk menjadi benda yang berfungsi selain fungsi } \\
\text { seharusnya? } \\
\text { - Apakah material dapat menginisasi anak untuk }\end{array}$ \\
\hline
\end{tabular}


bermain pura-pura?

\section{HASIL DAN PEMBAHASAN}

Sepuluh kelompok partisipan semuanya memilih untuk menggunakan penataan sentra. Karena masing-masing kelompok mensimulasikan pengembangan lima sentra, maka total ada 50 sentra yang dikembangkan dalam penelitian ini. Berikut adalah data lengkap dari seluruh sentra yang mereka kembangkan:

Tabel 2. Peta pengembangan sentra berdasar dokumen RPPH

\begin{tabular}{|l|l|l|}
\hline Nama Sentra & $\begin{array}{l}\text { Jumlah rencana pembelajaran } \\
\text { yang dikembangkan }\end{array}$ & Keterangan \\
\hline Sentra seni & 10 pengembangan & $\begin{array}{l}\text { Kel. 1, kel. 2 (2), kel. 3, kel. 4, kel. } \\
5 \text { (2), kel. 6, kel. 7, kel. 8, kel. 9, } \\
\text { kel. 10 (2) }\end{array}$ \\
\hline Sentra memasak & 2 pengembangan & Kel. 2, kel. 4, \\
\hline Sentra persiapan & 10 pengembangan & $\begin{array}{l}\text { Kel. 1, kel. 2, kel. 3, kel. 4, kel. 5, } \\
\text { kel. 6, kel. 7, kel. 8, kel. 9, kel. 10. }\end{array}$ \\
\hline Sentra balok & 7 pengembangan & $\begin{array}{l}\text { Kel. 1, kel. 2, kel. 3, kel. 6, kel. 8, } \\
\text { kel. 9, kel. 10 }\end{array}$ \\
\hline Sentra bahan alam & 8 pengembangan & $\begin{array}{l}\text { Kel. 1, kel. 3, kel. 4, kel. 5, kel. 6, } \\
\text { kel 7, kel. 8, kel. 9 }\end{array}$ \\
\hline $\begin{array}{l}\text { Sentra bermain } \\
\text { peran }\end{array}$ & 9 pengembangan & $\begin{array}{l}\text { Kel. 1, kel. 3, kel. 4, kel. 5, kel. 6, } \\
\text { kel. 7 (2), kel. 8, kel. 9, kel. 10 }\end{array}$ \\
\hline
\end{tabular}

Dari hasil analisa data, peneliti menggolongkan data temuan menjadi tiga kelompok. Kelompok data tersebut adalah rencana pembelajaran yang potensial untuk menginsiasi kegiatan (1) bermain tingkat rendah atau low level of play; (2) bermain tingkat menengah atau medium level of play; dan (3) bermain tingkat tinggi atau high level of play. Dari 50 data simulasi pengembangan pembelajaran sentra, ada enam rencana pengembangan (12\%) yang termasuk low level of play; ada 20 rencana pembelajaran yang termasuk medium level of play (40\%); dan ada 24 rencana pengembangan $(48 \%)$ termasuk high level of play.

Kegiatan bermain level tinggi atau high level of play dalam konteks ini adalah kegiatan pembelajaran yang mengandung enam prinsip bermain secara menyeluruh. Keenam prinsip tesebut adalah (1) menyenangkan, (2) motivasi instrinsik dari anak, (3) bebas dari aturan ekstrinsik, (4) keterlibatan aktif anak dengan objek/ material yang ada, (5) proses yang lebih penting dari hasil akhir (tidak ada produk tertentu yang diharapkan sebagai luaran), dan (6) melibatkan pemikiran abstrak sampai derajat tertentu (Rahardjo, 2016).

Sebaliknya, yang termasuk low level of play adalah rencana pembelajaran yang hanya $20 \%$ mengandung prinsip bermain. Dalam konteks ini berarti kegiatan pembelajaran tersebut hanya memenuhui salah satu kriteria prinsip bermain dari enam prinsip yang ada. Demikian pula dengan yang dimaksud rencana pembelajaran yang menginisiasi medium level of play adalah rencana 
pembelajaran yang ketika dianalisa hanya potensial untuk memenuhi 2-3 kriteria prinsip bermain $(20 \%-50 \%)$.

Berdasar tabel dan kriteria penggolongan yang telah dijelaskan, rencana pembelajaran yang disinyalir dapat menginisiasi low level of play dan medium level of play pada pembelajaran anak usia dini adalah rencana pembelajaran yang memiliki karakteristik sebagai berikut:

1. Kegiatan yang sifatnya instruksional, dalam kelompok besar, dan dipimpin guru.

Salah satu contoh rencana pembelajaran yang dikembangkan dan tidak mengandung prinsip bermain di dalamnya yaitu bernyanyi bersama. Ada dua kelompok yang dalam rencana pembelajarannya memilih untuk mengembangkan pembelajaran di sentra musik, tetapi bentuk kegiatannya adalah bernyanyi bersama-sama. Kegiatan bernyanyi bersama ini mungkin saja sesuatu yang menyenangkan, tetapi tidak dapat dikatakan bahwa kegiatan ini mengandung prinsip bermain. Bermain adalah sebuah konsep yang bukan hanya saja menyenangkan, tetapi juga melibatkan interaksi aktif seseorang dengan objek tertentu, melibatkan pemikiran abstrak sampai kadar tertentu, dan juga bebas dari peraturan eksternal. Pembelajaran bernyanyi bersama tidak bebas dari peraturan eksternal, yang dalam hal ini guru kelas menginstruksikan agar anak dapat mengikuti suatu gerakan tertentu, alokasi waktu tertentu, dan menyelesaikan sebuah lagu yang telah dipilihkan.

Tabel 3. Contoh-contoh rencana pembelajaran dan kategori bermainnya

\begin{tabular}{|c|c|c|}
\hline Level bermain & $\begin{array}{c}\text { Sentra yang } \\
\text { dikembangkan }\end{array}$ & $\begin{array}{c}\text { Contoh kegiatan dalam rencana } \\
\text { pebelajaran }\end{array}$ \\
\hline Low level of play & $\begin{array}{l}\text { (tidak ada sentra } \\
\text { khusus) }\end{array}$ & $\begin{array}{l}\text { - Menyanyi bersama dalam kelompok } \\
\text { besar bersama guru. } \\
\text { - Bermain bersama dalam kelompok } \\
\text { besar bersama guru. }\end{array}$ \\
\hline \multirow[t]{3}{*}{$\begin{array}{l}\text { Medium level of } \\
\text { play }\end{array}$} & Sentra seni & $\begin{array}{ll}- & \text { Membuat sate buah } \\
\text { - } & \text { Membuat montase } \\
\text { - } & \text { Membuat origami } \\
\text { - } & \text { Membuat benda 3D (mobil, kereta, dan } \\
& \text { sebagainya) dari barang bekas. }\end{array}$ \\
\hline & Sentra bahan alam & $\begin{array}{ll}\text { - } & \text { Menanam bunga bersama } \\
\text { - } & \text { Mencuci sayur bersama }\end{array}$ \\
\hline & Sentra persiapan & $\begin{array}{l}\text { - Mencocokkan angka dengan jumlah } \\
\text { gambar yang ada pada papan menali } \\
\text { - Memilih kartu angka yang sesuai } \\
\text { dengan jumlah benda yang ada. }\end{array}$ \\
\hline \multirow[t]{2}{*}{ High level of play } & Sentra main peran & $\begin{array}{l}\text { - Sentra ditata dengan material dan } \\
\text { penataan yang menggambarkan toko } \\
\text { buah/ toko sayur/ toko bunga. } \\
\text { - Sentra ditata seperti kota dan } \\
\text { pelabuhan, lengkap dengan kapal } \\
\text { mainan dan perlengkapannya }\end{array}$ \\
\hline & Sentra balok & $\begin{array}{l}\text { - Guru memberi contoh balok yang } \\
\text { dibentuk menjadi aneka binatang/ } \\
\text { bunga/ lain-lain tetapi tidak membatasi } \\
\text { kreasi anak. }\end{array}$ \\
\hline
\end{tabular}


Selain bernyanyi bentuk kegiatan terpimpin lain yang juga bukan merupakan bermain adalah 'permainan kejar mengejar hewan'. Meskipun judulnya permainan, tetapi kegiatan ini memiliki aturan-aturan tertentu yang harus diikuti oleh seseorang yang terlibat di dalamnya. Aturan tersebut dibuat oleh guru dan anak tersebut harus mengikuri instruksi-instruksi yang ada di dalamnya untuk membuat permainan ini berjalan lancar. Meskipun anak berpartisipasi aktif di dalamnya dan mungkin saja kegiatan ini menyenangkan, tetapi kegiatan ini diinisiasi dari guru dan karenanya bukan merupakan motivasi intrinsik dari anak tersebut. Mempertimbangkan beberapa aspek tersebut, maka permainan ini tidak murni mengandung semua prinsip bermain. Beberapa literatur menyebutkan bahwa bentuk kegiatan ini merupakan salah satu bentuk 'permainan dengan aturan' atau games with rules (Johnson, Christie, and Wardle, 2005).

2. Kegiatan pembelajaran yang miskin material dan penataan.

Dari enam rencana pembelajaran yang tidak menginisiasi high level of play, ada sebuah rencana pembelajaran yang disebabkan karena minimnya material dan penataan di dalamnya. Salah satu kelompok menuliskan dalam dokumen RPPHnya "sentra bermain peran: anak-anak dapat bermain memetik sayur dan jual beli sayur". Tetapi pada praktiknya, kelompok tersebut tidak menyediakan material apa pun dan hanya membawa satu pot tanaman bayam yang diletakkan di sudut ruangan. Hasil diskusi dan wawancara dengan kelompok tersebut menghasilkan kesimpulan bahwa meskipun kelompok menyiapkan pot, persentase untuk terjadi kegiatan bermain peran seperti yang direncanakan di RPPH adalah sangat rendah. Kemungkinan yang terjadi adalah anak-anak akan hanya menganggap pot tersebut sebagai salah satu hiasan kelas yang baru. Beberapa anak mungkin mendekati dan mengamati pot, atau berinteraksi dengan pot seperti menyentuh tanaman atau bertanya pada guru tentang jenis tanaman tersebut, tetapi tidak akan terjadi kegiatan bermain peran petik-memetik sayur atau jual beli.

Diskusi dan wawancara juga mengungkap bahwa supaya kegiatan bermain peran seperti yang ada dalam RPPH dapat terjadi, guru kelas harus menyediakan material yang memadai dan menatanya. Sebagai contoh, guru dapat menyediakan berbagai macam sayuran (seperti kacang panjang, wortel, buncis), keranjang belanja, kardus sebagai mesin kasir, kertas sebagai uang, dan beberapa perlengkapan jual beli lainnya. Selanjutnya, semua material tersebut tidak hanya diletakkan ala kadarnya, tetapi ditatai seperti layaknya sebuah toko sayur. Dengan demikian, material dan penataan yang menarik akan mengundang anak untuk berinteraksi aktif dengan objek. Ketika anak terundang, maka hal tersebut merupakan motivasi intrinsik dari anak tersebut sehingga ia akan melakukan permainan dengan perasaan senang. Penataan dan material yang disiapkan juga tidak memberi 'instruksi' yang mengekang proses bermain anak. Ia dapat mengatur tempo permainan dan skenario permainan. Hal tersebut menjadikan kegiatan tersebut bebas dari aturan eksternal.

Dari pembahasan ini dapat disimpulkan bahwa salah satu syarat terjadinya high level of play adalah tersedianya material yang memadai dan sekaligus penataan lingkungan bermain tempat material tersebut ditempatkan. Kesimpulan ini sejalan dengan penelitian yang dilakukan oleh Walker and Spybrook (2013) yang pada dasarnya adalah merupakan adopsi filosofi pendekatan Reggio Emilia yang menyatakan bahwa lingkungan adalah guru ketiga (StrongWilson and Ellis, 2007; You, Osborne, and Franz, 2015).

3. Terlalu fokus pada produk akhir yang dihasilkan

Beberapa contoh rencana pembelajaran yang disinyalir akan menginisiasi pembelajaran medium level of play adalah rencana-rencana pembelajaran yang memiliki hasil akhir berupa produk tertentu. Sentra yang sangat potensial untuk menginisiasi pembelajaran medium level of play adalah sentra seni dan sentra memasak. Sebagai contoh, dalam pembelajaran membuat sate 
buah, guru mengharapkan anak-anak nantinya dapat menghasilkan produk akhir berupa sate buah. Meskipun kegiatan pembelajaran ini melibatkan interaksi dengan benda nyata dan mungkin sangat menyenangkan, tetapi dalam kegiatan ini ada aturan eksternal tertentu yang harus diikuti untuk menghasilkan produk akhir yang diharapkan. Dari hasil diskusi juga ada kecenderungan dari guru untuk membatasi jika dirasa nantinya ada siswa yang akan menggunakan potongan buah untuk kegiatan main peran. Berikut kutipan jawaban dari pertanyaan "bagaimana jika seandainya nanti ada anak yang tidak menusuk potongan buah ini di tusuk sate tetapi menyusun di piringpiring kecil dan main dengan boneka di sentra peran?"

"Ya, kami akan berusaha arahkan dan beri pengertian supaya anak kembali ke sentra memasak. Kami akan damping khusus karena mungkin anak tersebut bosan dan kurang mampu membuat sate buah."

Dari jawaban yang diberikan, jelas bahwa produk akhir yang diharapkan hanya dapat dihasilkan jika anak mengikuti prosedur tertentu dalam membuat sate buah. Sering kali guru fokus pada kegiatan daripada tujuan. Mereka lupa bahwa kegiatan membuat sate buah adalah sarana untuk mengembangkan suatu aspek perkembangan tertentu (motorik halus misalnya) dan dapat dicapai oleh kegiatan pembelajaran lain.

Selanjutnya, penulis akan membahas rencana pembelajaran yang dirasa dapat menginisiasi high level of play. Data yang ada menunjukkan bahwa sentra bermain peran dan sentra balok adalah dua sentra yang potensial untuk dapat terjadinya sebuah pembelajaran yang mengandung keseluruhan prinsip bermain. Bertolak dari pembahasan sebelumnya, dapat disimpulkan bahwa minimal ada dua faktor penenentu pembelajaran yang mengintegrasikan high level of play di dalamnya. Faktor pertama adalah material dan penataannya (lingkungan) dan faktor kedua adalah guru. Guru yang dapat mengintegrasikan high level of play ke dalam pembelajarannya adalah guru yang memahami tujuan pembelajaran dengan baik dan memahami bahwa ada lebih dari satu bentuk kegiatan pembelajaran untuk mencapai tujuan tersebut.

\section{Mengapa High Level of Play?}

Pertanyaan selanjutnya adalah mengapa seorang guru perlu menyediakan pengalaman pembelajaran yang dapat mengintegrasikan high level of play? Jawaban dari pertanyaan ini dapat ditelusuri dari enam karakteristik high level of play yang sudah disebutkan sebelumnya. Pertama, karakteristik bermain adalah berasal dari motivasi intrinsik anak. Motivasi adalah sumber energi untuk seseorang dapat mempertahankan fokus, atensi, dan minat pada suatu pekerjaan tertentu (Ryan and Deci, 2000). Berdasar definisi tersebut, jika bermain adalah bersumber dari motivasi dari dalam diri si anak, maka anak tersebut akan fokus, memperhatikan, dan melakukan aktivitas tersebut dalam waktu lama. Fokus dan perhatian tersebut pada akhirnya dapat membuat pengalaman belajar anak menjadi dalam dan bermakna (Van Hoorn, Nourot, Scales, and Alward, 2011).

Karakteristik bermain yang selanjutnya adalah menyenangkan. Karakteristik ini berkaitan dengan emosi anak. Perasaan senang adalah salah satu emosi dasar manusia. Penelitian ilmiah menyebutkan bahwa perasaan senang dapat menunjang pembelajaran. Sebaliknya, emosi negatif yang timbul karena paksaan guru untuk melakukan hal-hal yang instruksional dan tidak sesuai dengan kemampuan anak dapat membawa anak pada situasi stress. Situasi stress berkepanjangan dapat menjadi 'racun' dan mempengaruhi semua aspek perkembangan anak (kesehatan, kognitif, sosial, emosional) sampai ia dewasa (Shonkoff et al., 2012).

Ketiga, karakteristik 'bebas dari aturan ekstrinsik' dan 'proses lebih penting daripada hasil' membuat anak dapat memilih dan menetukan tingkat kesulitan pembelajaran yang sesuai dengan kemampuannya. Anak dapat mengambil waktu sebanyak yang ia butuhkan untuk mempelajari sebuah 
konsep pembelajaran tertentu. Dengan demikian, ia menjadi pembelajar yang kompeten dan percaya diri karena penguasaan pembelajaran berada dalam kontrol anak tersebut (Rahardjo, 2016)

Terakhir, keterlibatan aktif anak dengan objek/ material yang ada juga dirasa akan sangat mendukung proses pembelajaran pada anak usia dini. Hal ini sesuai dengan teori Piaget yang mengatakan bahwa anak usia dini masih berada pada tahap pra-operasional dan oleh karenanya akan sangat terbantu ketika mereka belajar dari sebuah benda konkrit (Berk, 2008).

\section{SIMPULAN}

Pendekatan bermain merupakan pendekatan pembelajaran yang efektif bagi anak usia dini. Berbagai studi yang dilakukan menguatkan hal tersebut. Oleh karena itu, pendekatan bermain telah banyak diadopsi ke dalam kurikulum PAUD di berbagai negara, termasuk di Indonesia. Dari hasil penelitian, ada beberapa hal yang menjadi catatan penting bagi seorang guru untuk dapat mengembangkan pembelajaran yang dapat mengintegrasikan high level of play, yaitu pemilihan material yang digunakan dalam pembelajaran, penataan lingkungan fisik (termasuk penataan material yang telah dipilih), dan kemampuan guru tersebut dalam mengantisipasi penggunaan material/ aktivitas yang secara spontan terjadi diluar hal yang telah direncanakan. Lebih tegas lagi disimpulkan bahwa high level of play perlu diintegrasikan ke dalam pembelajaran anak usia dini karena karakteristiknya dapat mengoptimalkan pembelajaran yang berlangsung.

Penelitian ini memiliki keterbatasan yaitu semua rencana pembelajarannya belum diimplementasikan secara nyata dalam situasi pembelajaran di kelas sesungguhnya. Oleh karenanya, penelitian selanjutnya sebaiknya masuk ke tahap implementasi rencana pembelajaran untuk sekaligus melihat apakah analisa teoritis yang dibahas dalam tulisan ini sesuai dengan praktik di lapang.

\section{DAFTAR PUTAKA}

Berk. L. E. (2009). Child development. 8th edn. Boston: Peason.

Bodrova, E. \& Leong, D. J. (2003). The importance of being playful. Educational Leadership, April: $50-53$.

Johnson, J. E., Christie, J. F., \& Wardle, F. (2005). Play, development and early education. Boston; London: Pearson/ Allyn and Bacon.

Kementrian Pendidikan dan Kebudayaan. (2009). Peraturan Menteri Pendidikan Nasional Republik Indonesia nomor 58 tahun 2009 tentang Standar Pendidikan Anak Usia Dini. Retrieved from http://staff.uny.ac.id/sites/default/files/tmp/KKN\%20BANTUL\%20PERMEN\%2058.pdf.

Kementrian Pendidikan dan Kebudayaan. (2014a). Peraturan Menteri Pendidikan dan Kebudayaan Republik Indonesia nomor 57 tahun 2014 tentang Kurikulum 2013 Sekolah Dasar/ Madrasah Ibtidaiyah - Lampiran I tentang Kerangka Dasar Kurikulum dan Struktur Kurikulum Sekolah Dasar/ Madrasah Ibtidaiyah. Retrieved from http://staff.unila.ac.id/ngadimunhd/files/2012/03/Permendikbud-No-146-2014.pdf

Kementrian Pendidikan dan Kebudayaan. (2014b). Peraturan Menteri Pendidikan dan Kebudayaan Republik Indonesia nomor 137 tahun 2014 tentang Standar Nasional Pendidikan Anak Usia Dini. Retrieved from http://anggunpaud.kemdikbud.go.id/upload/resources/documents/4578bf5cf57c0c02f561eb987 7640043.pdf. 
Kementrian Pendidikan dan Kebudayaan. (2014c). Peraturan Menteri Pendidikan dan Kebudayaan Republik Indonesia nomor 146 tahun 2014 tentang Kurikulum 2013 Pendidikan Anak Usia Dini. Retrieved from http://anggunpaud.kemdikbud.go.id/upload/resources/documents/9fd52fb7f99ebfc70a46f2de4a fd128c.pdf.

Nazir, M. (2005). Metode Penelitian. Bogor: Ghalia Indonesia.

Rahardjo, M.M. (2016). Sebuah pengingat bagi kebijakan bermain pada kurikulum pendidikan anak usia dini. Widya Sari, 18 (3): 103 - 110.

Ryan, R. M. \& Deci, E. L. (2000). Self-determination theory and the facilitation of intrinsic motivation, social development, and well-being. American psychologist, 55(1), 68 - 78.

Sanjaya, W. (2008). Kurikulum dan pembelajaran: Teori dan praktik pengembangan KurikulumTingkat Satuan Pendidikan (KTSP). Jakarta: Kencana Prenada Media Group.

Sanjaya, W. (2013). Penelitian pendidikan: Jenis, metode, dan prosedur. Jakarta: Kencana Prenada Media Grup.

Shonkoff, J. P., Garner, A. S., Siegel, B. S., Dobbins, M. I., Earls, M. F., McGuinn, L., .. \& W Wood, D. L. (2012). The lifelong effects of early childhood adversity and toxic stress. Pediatrics, 129 (1), e232 - e246.

Strong-Wilson, T \& Ellis, J. (2007). Children and place: Reggio Emilia's environment as third teacher. Theory Into Practice, 46(1): pp. $40-47$.

Van Hoorn, J., Nourot, P. M., Scales, B., \& Alward, K. R. (2011). Play at the center of the curriculum. Upper Saddle River, N.J: Pearson Education.

Walker, S. L. \& Spybrook, J. (2013). Planning for play environments with pre-service teachers. Preparing Effective Leaders for Tommorrow's Schools, 1.

Wolfgang, C. H. \& Wolfgang, M. E. (1992). School for young children: Developmentally appropriate practice. Needham Heights, MA: Allyn and Bacon.

You, H., Osborne, L, \& Franz, J. (2015). Reflecting on Reggio: An evaluation of design intent in an early childhood learning environment. Creative Engagements: Thinking with Children.

Downloaded from http://eprints.qut.edu.au/ 91107/ 